\title{
Melatonin receptors in red deer fetuses (Cervus elaphus)
}

\author{
L. M. Williams, L. T. Hannah, C. L. Adam and D. A. Bourke \\ Rowett Research Institute, Greenburn Road, Bucksburn, Aberdeen AB21 9SB, UK
}

\begin{abstract}
Red deer (Cervus elaphus) exhibit highly seasonal rhythms in physiology and behaviour. The influence of photoperiod on the timing of these changes begins in utero where the fetus receives photoperiodic information via the diurnal pattern of maternal melatonin secretion. The potential sensitivity of deer fetuses to melatonin was ascertained by mapping specific receptors and characterizing them using $2-\left[{ }^{125} \mathrm{I}\right]$ iodomelatonin and quantitative autoradiography in vitro. Specific binding occurred from day 31 of gestation onwards (term $=233$ days) over the spinal nerves and respiratory system. At later stages of gestation binding occurred over the brain, particularly the brainstem, the pituitary gland, thyroid gland, gastrointestinal tract including the pancreas, metanephros, cochlea of the ear, spinal cord, and spinal and cranial nerves. Binding was abolished in the presence of $10^{-7}$ mol melatonin $\mathrm{l}^{-1}$ and diminished in the presence of $10^{-4} \mathrm{~mol}$ GTP $\gamma \mathrm{S} \mathrm{l}^{-1}$ (guanosine-5-0(3-thiotriphosphate)), confirming that binding represented functional G-protein-coupled melatonin receptors. Characterization studies, carried out on fetal lung, revealed that binding was time-dependent, reaching equilibrium at about $3 \mathrm{~h}$ at room temperature $\left(22^{\circ} \mathrm{C}\right)$, and saturable with a dissociation constant $\left(K_{\mathrm{d}}\right)$ of $104 \mathrm{pmol} \mathrm{I}^{-1}$. This study demonstrates the presence of G-protein-coupled melatonin receptors over a wide range of tissues in red deer fetuses from early in gestation, indicating that in addition to its role in the communication of photoperiodic information to the fetus in this species, melatonin may be involved in fetal growth and development.
\end{abstract}

\section{Introduction}

Variations in the maternally experienced photoperiod during gestation influence the subsequent rate of sexual development in the offspring in seasonally breeding rodents (Horton, 1984 and 1985; Lee et al., 1989; Stetson et al., 1986 and 1989). Sheep and deer are also sensitive to the effects of maternally perceived photoperiod (Helliwell et al., 1992; Adam et al., 1994). In hamsters these effects are communicated via the maternal melatonin signal (Weaver and Reppert, 1986; Weaver et al., 1987). Since maternal melatonin passes to sheep fetuses (Zemdegs et al., 1988), and given the similarity in placentation with the deer (Steven, 1975), it is reasonable to propose that maternal melatonin may reach fetal deer in a similar manner, thus providing a mechanism for communicating photoperiodic information. Melatonin receptors have been identified in fetal tissues of several species, including rats (Williams et al., 1991), Djungarian and Siberian hamsters (Weaver et al, 1988; Carlson et al., 1991; Rivkees and Reppert, 1991) and sheep (Helliwell and Williams, 1994). Quantitative autoradiography of 2-[ ${ }^{125}$ I]iodomelatonin was used in vitro to localize and characterize melatonin receptors during development to confirm the sensitivity of the deer fetus melatonin during gestation.

Received 6 November 1996

\section{Materials and Methods}

\section{Tissues}

Red deer (Cervus elaphus) hinds (average live weight $95 \mathrm{~kg}$ ) were kept outdoors with grazing and supplementary feed to appetite and allowed to mate naturally during a two week period in October. Pregnant hinds were killed either by captive bolt or by a lethal dose of sodium pentobarbitone (Euthesate, Willows Francis Veterinary, Sussex), $0.5 \mathrm{ml} \mathrm{kg}^{-1}$ given intravenously. Fetuses (all singletons) were killed by an intra-cardiac injection of Euthesate. All procedures complied with the Animals (Scientific Procedures) Act 1986. Gestational ages of fetuses were estimated from observed mating dates and crown-rump length measurements (Adam et al., 1988 and C. L. Adam, unpublished). All tissues were collected during the late morning and frozen immediately in isopentane chilled over dry ice. Fetuses (male and female) were collected at gestational ages: 26 days $(n=1), 31-33$ days $(n=3), 36-38$ days $(n=3), 43-48$ days $(n=3), 56-62$ days $(n=3)$ and 192 days $(n=1)$.

\section{Receptor autoradiography}

Cryostat sections of fetal tissue, $20 \mu \mathrm{m}$ in thickness, were cut and thaw-mounted on to gelatin-coated slides. The localization 

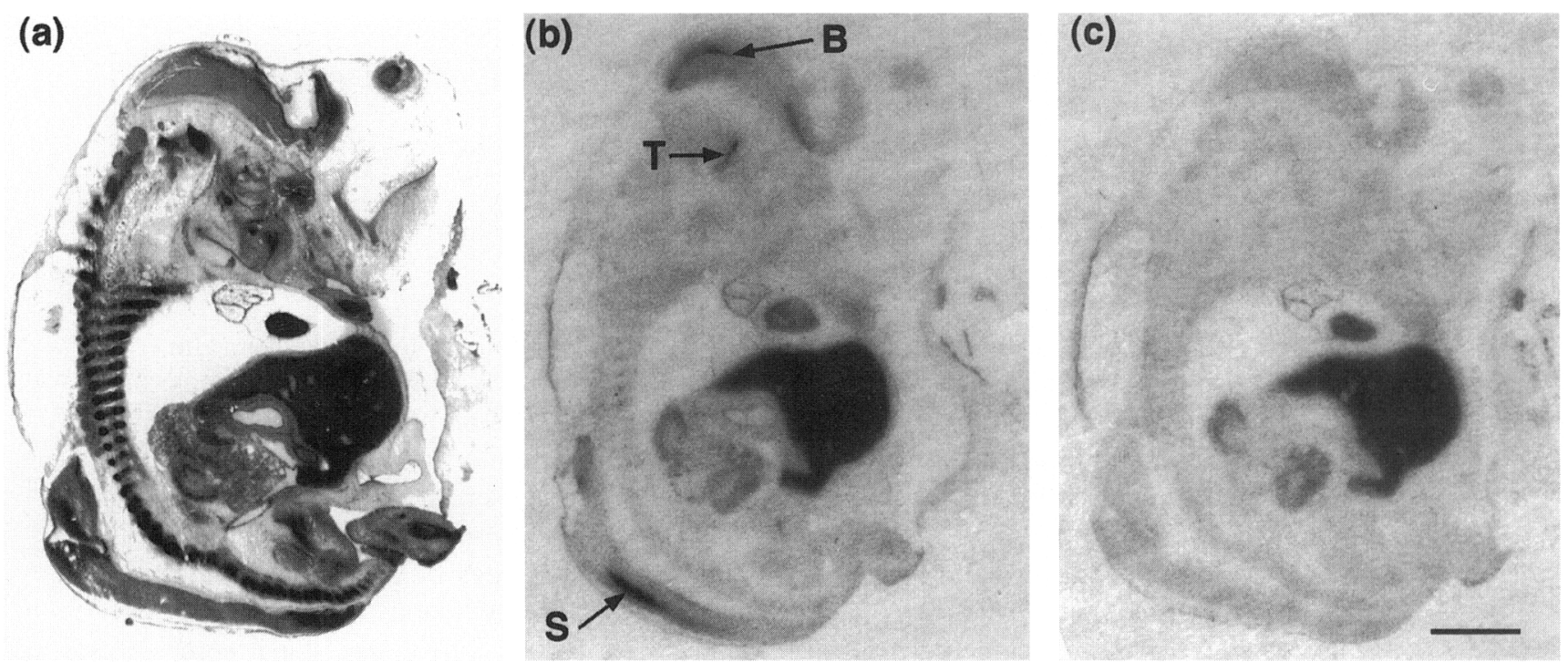

Fig. 1. Serial sagittal sections of a fetus at day 36 showing (a) toluidine blue stained section, (b) total $2-\left[{ }^{125} \mathrm{l}\right] \mathrm{iodomelatonin}$ binding, and (c) binding in the presence of $10^{-7} \mathrm{~mol}$ melatonin $\mathrm{l}^{-1}$. Specific $2-\left[{ }^{125} \mathrm{I}\right]$ iodomelatonin binding was localized over the brain $(B)$, trachea $(\mathrm{T})$, and spinal cord (S). Scale bar represents $2.8 \mathrm{~mm}$.

(a)

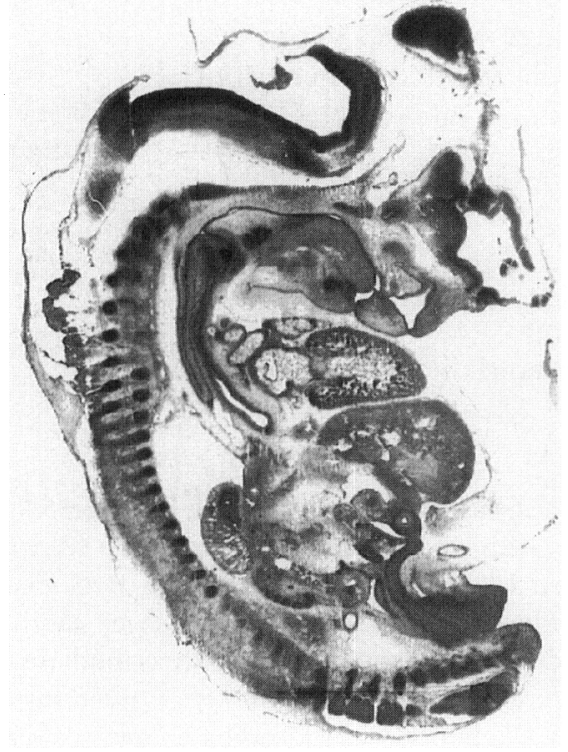

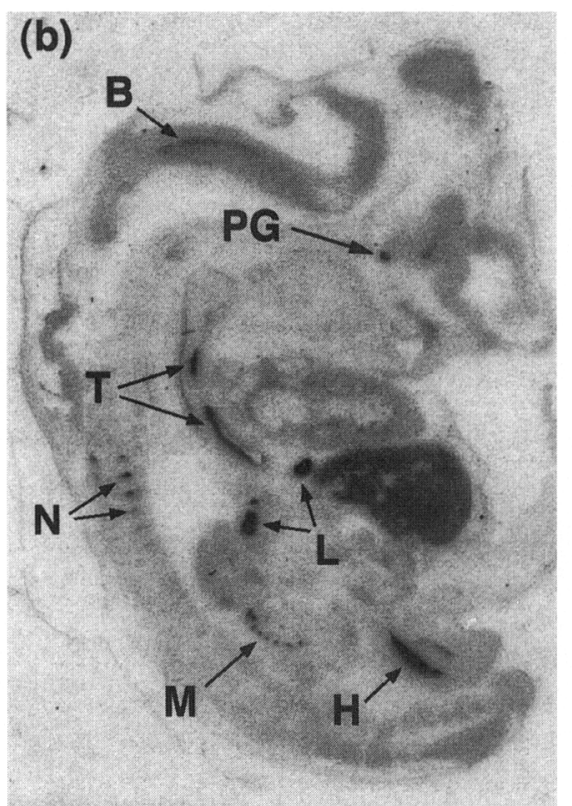

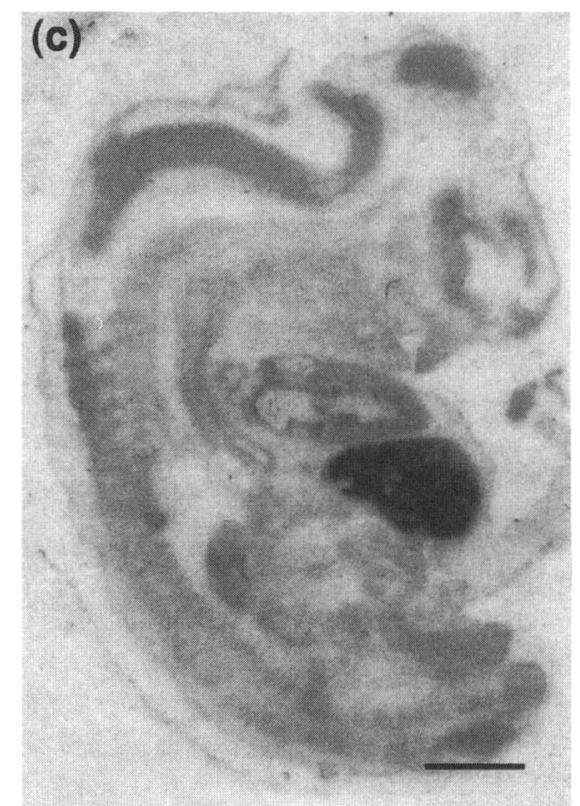

Fig. 2. Serial sagittal sections of a fetus at day 38 showing (a) toluidine blue stained section, (b) total 2-[ $\left.{ }^{125} \mathrm{I}\right]$ iodomelatonin binding, and (c) binding in the presence of $10^{-7} \mathrm{~mol}$ melatonin $1^{-1}$. Specific $2-\left[{ }^{125} \mathrm{l}\right]$ iodomelatonin binding was localized over the brain (B), pituitary gland (PG), trachea (T), lung buds $(\mathrm{L})$, metanephros $(\mathrm{M})$, hindgut $(\mathrm{H})$ and the spinal nerves $(\mathrm{N})$ Scale bar represents $2.6 \mathrm{~mm}$.

and characterization of $2-\left[{ }^{12.5}\right.$ I] iodomelatonin binding sites were carried out as described by Helliwell and Williams (1992). Briefly, slides were incubated with 2-[ ${ }^{125}$ I] iodomelatonin (NEN Dupont Ltd, Stevenage, Herts), at $80-100 \mathrm{pmol} \mathrm{I}^{-1}$ in $25 \mathrm{mmol}$ Tris- $\mathrm{HCl} \mathrm{l}^{-1}$ buffer containing $4 \mathrm{mmol} \mathrm{CaCl}_{2} \mathrm{l}^{-1}$, in the presence or absence of either $10^{-7}$ mol melatonin $l^{-1}$ or $10^{-4}$ mol guanosine 5-0-(3-thiotriphosphate) (GTP $\left.\gamma \mathrm{S}\right) 1^{-1}$, for $3 \mathrm{~h}$ at room temperature $\left(22^{\circ} \mathrm{C}\right)$. For time-course studies, incubations were carried out for progressively longer periods between $5 \mathrm{~min}$ and $5 \mathrm{~h}$. Competition curves were generated by incubating serial sections with approximately $100 \mathrm{pmol}$ $2-\left[{ }^{125} \mathrm{I}\right]$ iodomelatonin $\mathrm{I}^{-1}$ in the presence of increasing concentrations of either iodomelatonin (RBI, MA), melatonin, or serotonin (5-HT). Slides were then washed in ice-cold buffer, air dried and apposed to Kodak X-OMAT AR film along with [ $\left.{ }^{125} \mathrm{I}\right]$ Polymer Standards (Amersham International, Little Chalfont, Bucks). Films were exposed for between 2 and 6 weeks and optical densities measured using a Torch Quad X Work Station (Torch Computers, Cambridge, UK). Absorbance readings were converted to $\mathrm{fmol} \mathrm{mg}^{-1}$ protein according to 

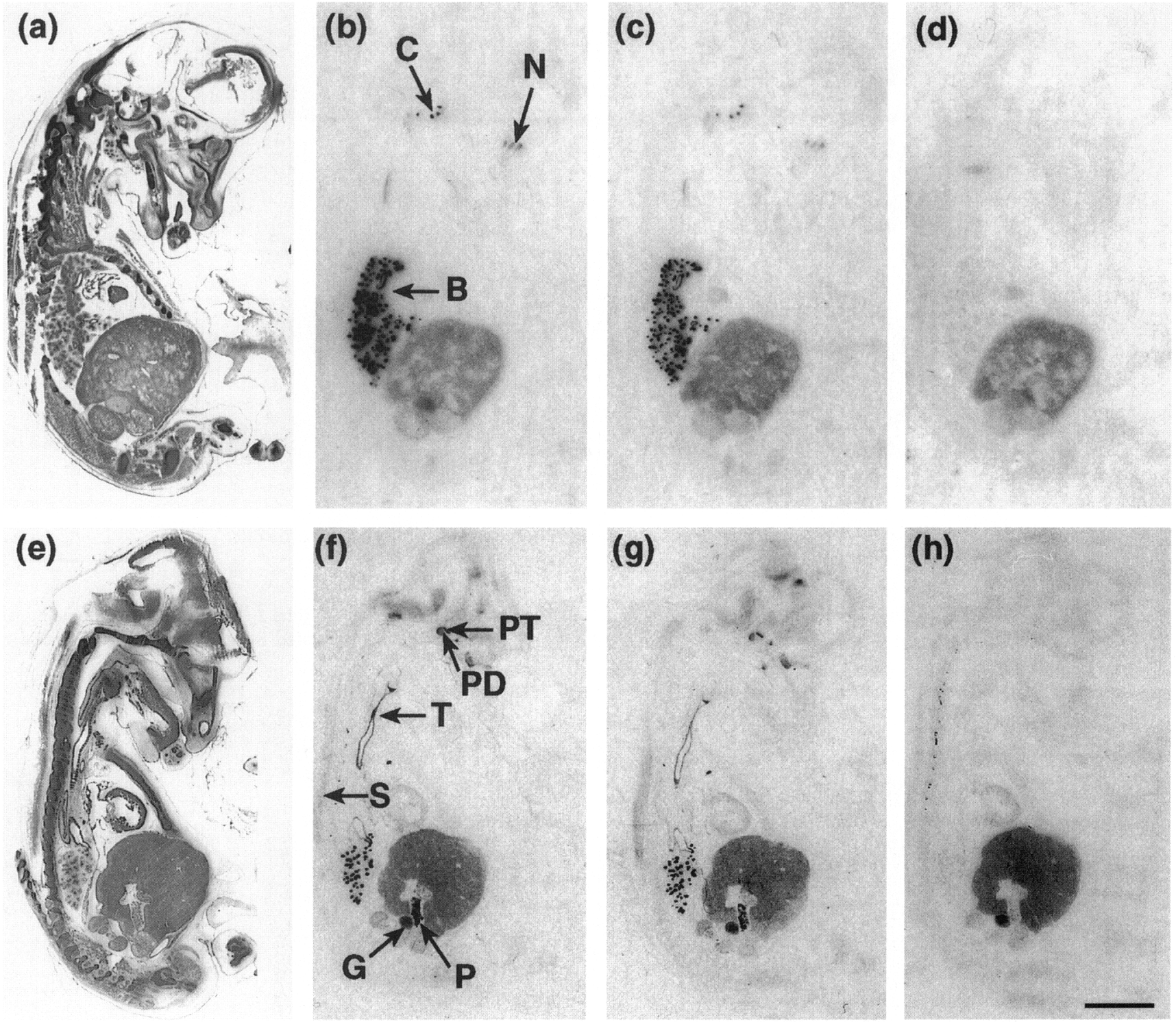

Fig. 3. Serial sagittal sections of a fetus at day 48 showing $(a, e)$ toluidine blue stained section, $(b, f)$ total $2-\left[{ }^{125}\right.$ I]iodomelatonin binding, $(\mathrm{c}, \mathrm{g}) 2-\left[{ }^{125} \mathrm{I}\right]$ iodomelatonin binding in the presence of $10^{-4} \mathrm{~mol} \mathrm{GTP \gamma S} \mathrm{l}^{-1}$, and $(\mathrm{d}, \mathrm{h}) 2-\left[{ }^{125} \mathrm{I}\right]$ iodomelatonin binding in the presence of $10^{-7}$ mol melatonin $1^{-1}$. Specific binding is located over the cochlea innervation $(C)$, the nasal epithelium $(N)$, the trachea $(T)$, the bronchi $(B)$, the pars tuberalis (PT) the pars distalis (PD) of the pituitary, the pancreas $(\mathrm{P})$ and the spinal cord (S). Non-specific binding can be seen over the genital ridge $(\mathrm{G})$. Scale bar represents $6 \mathrm{~mm}$.

Nazarali et al. (1990). Labelled tissues were identified by staining sections either immediately with toluidine blue or by coating in LM-I liquid emulsion (Amersham International, Little Chalfont, Bucks, UK) for autoradiography. Labelled tissues were identified by comparison with the rat fetus (Paxinos et al., 1994) and the pig fetus (Arey, 1974).

Saturation isotherms were carried out using crude membrane homogenates of fetal lung (192 days gestation), as previously described (Morgan et al., 1989), and used increasing concentrations of $2-\left[{ }^{125} I\right]$ iodomelatonin between 15 and $900 \mathrm{pmol}$ $1^{-1}$. Data from saturation isotherms and competition studies were analysed using Grafit (Sigma International, Poole, Dorset). All chemicals were obtained from Sigma International (Poole, Dorset) unless otherwise stated.

\section{Results}

Data were pooled from male and female fetuses since preliminary observations detected no apparent differences in the localization of binding. Specific $2-\left[{ }^{125} I\right]$ iodomelatonin binding was first identified during gestation over the spinal nerves and lung buds of a 31 day gestation fetus (crown-rump length $(C R L)=13 \mathrm{~mm}$ ) and a 32 day fetus $(C R L=14 \mathrm{~mm}$ ) (not shown); however a 33 day fetus $(C R L=15 \mathrm{~mm})$ revealed no specific labelling. Specific binding of $2-\left[{ }^{125} \mathrm{I}\right]$ iodomelatonin in sections from a day 36 fetus (CRL $=17 \mathrm{~mm}$ ) (Fig. 1) was identified over the trachea, brain and spinal cord and also over the spinal nerves and lung buds (not shown). By day 38 of gestation $(C R L=20 \mathrm{~mm})$ onwards, specific binding was found 
(a)

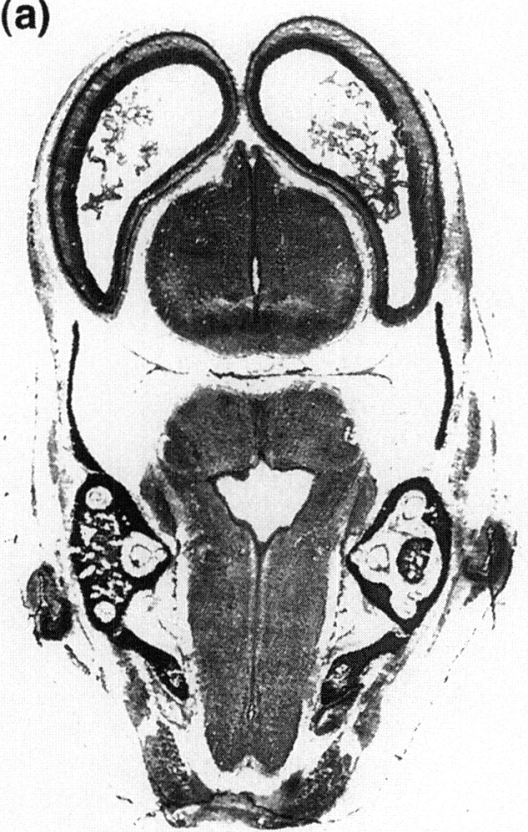

(b)

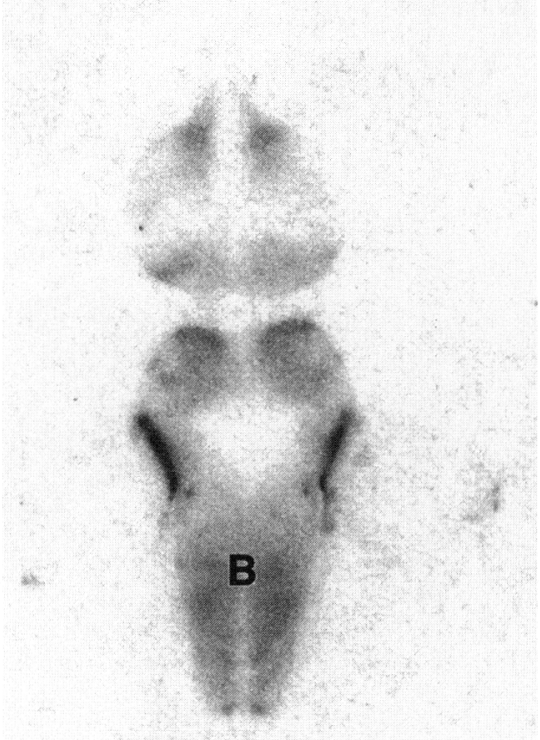

(c)

Fig. 4. Serial coronal oblique sections of a fetus at day 52 showing (a) toluidine blue stained section, (b) total $2-\left[{ }^{125}\right.$ I]iodomelatonin binding, and (c) $2-\left[{ }^{125} \mathrm{I}\right]$ iodomelatonin binding in the presence of $10^{-7}$ mol melatonin $I^{-1}$. Specific binding is located over the brainstem (B). Scale bar represents $2 \mathrm{~mm}$.
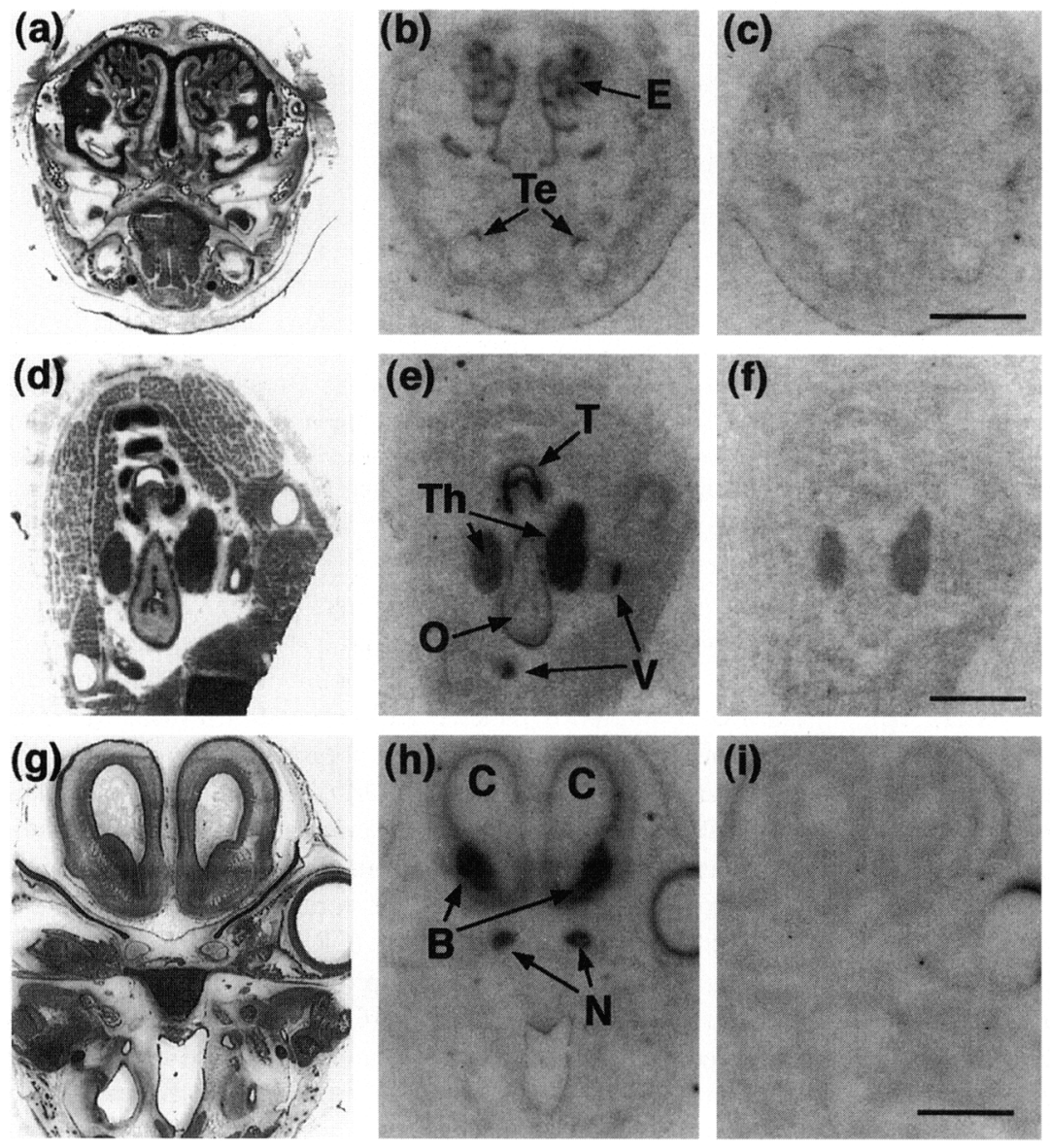

Fig. 5. Serial coronal sections of a fetus at day 62 showing $(a, d, g)$ toluidine blue stained sections, $(b$, $e, h)$ total $2-I^{125}$ I]iodomelatonin binding, and $(c, h, i)$ $2-\left[{ }^{125} \mathrm{I}\right]$ iodomelatonin binding in the presence of $10^{-7}$ mol melatonin $1^{-1}$. Specific binding can be seen over the nasal epithelium $(\mathrm{E})$, teeth $(\mathrm{Te})$, trachea (T), thyroid gland (Th), oesophagus $(\mathrm{O})$, vagosympathetic trunk $(\mathrm{V})$, cerebral hemispheres $(\mathrm{C})$, the base of the telenchephalon (B) and optic nerves $(N)$. Scale bars represent $4.2 \mathrm{~mm}(\mathrm{a}, \mathrm{b}, \mathrm{c}), 2.5 \mathrm{~mm}(\mathrm{~d}, \mathrm{e}, \mathrm{f})$ and $4.6 \mathrm{~mm}(\mathrm{~g}, \mathrm{~h}, \mathrm{i})$. 

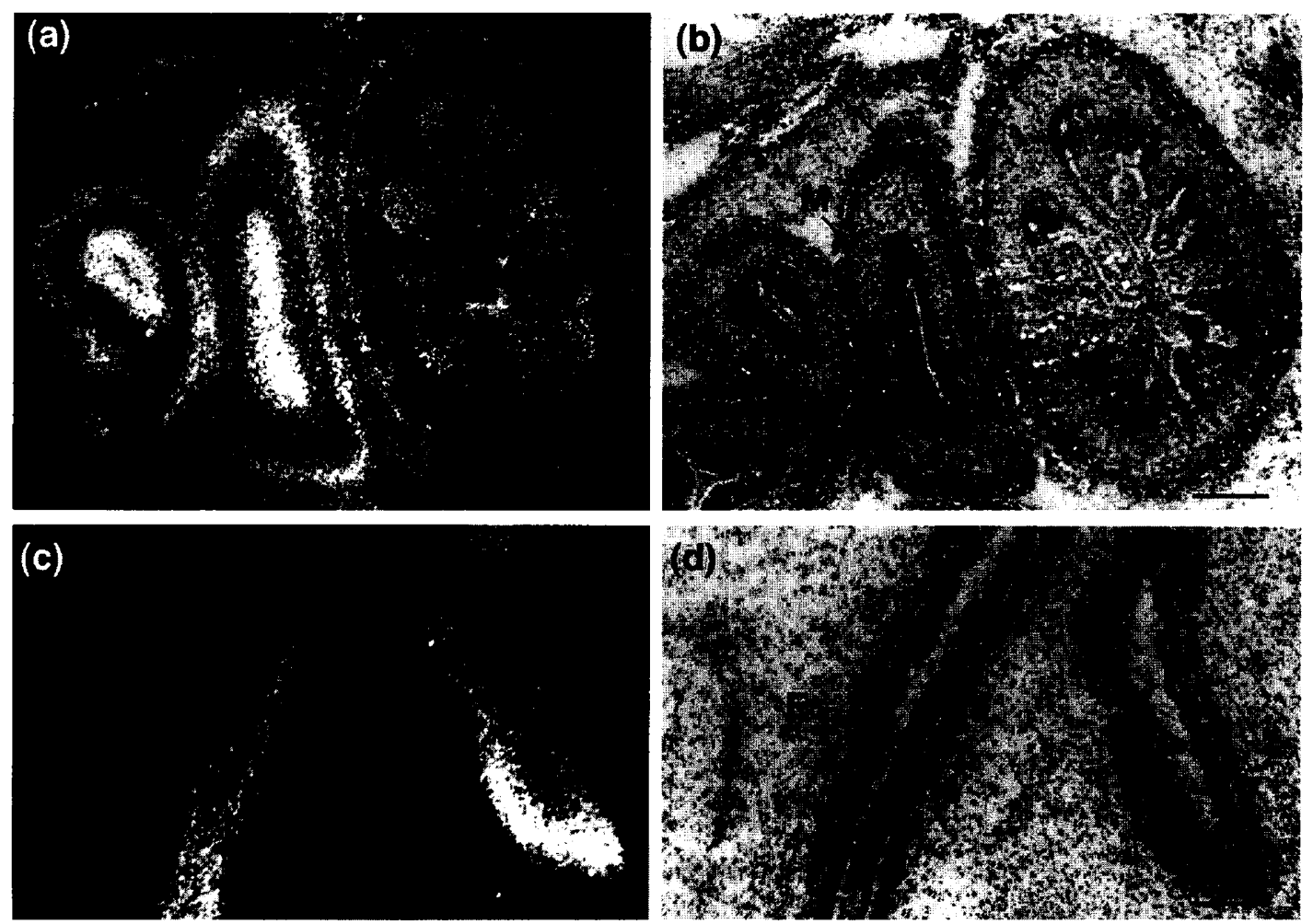

Fig. 6. Serial sagittal sections of a fetus at day 48 showing $(a, c)$ dark-field autoradiography of 2-[ $\left.{ }^{125} \mathrm{I}\right]$ iodomelatonin binding, and $(b, d)$ corresponding bright field images. Silver grains appear white and overlie the mucosa (M) and muscular stroma $(S)$ in the gastrointestinal tract $(a, b)$ and the bronchial epithelium (E) in the respiratory system $(c, d)$. Scale bars represent $190 \mu \mathrm{m}$.

over the brain, spinal cord, spinal nerves, pituitary gland, trachea, lung buds, gastrointestinal tract and metanephros (Fig. 2). At 48 days (CRL $=38 \mathrm{~mm}$ ) onwards, specific binding was also identifiable over the nasal epithelium, the cochlear innervation and throughout the gastrointestinal tract including the pancreas (Fig. 3), as well as in the regions previously identified. Specific 2-[ $\left.{ }^{125} \mathrm{I}\right]$ iodomelatonin binding could also be clearly distinguished over the pars tuberalis and pars distalis of the pituitary gland (Fig. 3). Non-specific binding was detected over the genital ridge. At 52 days onwards, high concentrations of specific $2-\left[{ }^{125}\right.$ I]iodomelatonin binding were apparent over the brainstem (Fig. 4). Coronal sections through the head and neck regions of a 62 day fetus revealed specific labelling over the nasal epithelium, teeth (Fig. 5a), thyroid gland, oesophagus and larynx and the vagosympathetic trunk (Fig. 5b). Specific binding was also found in the brain over the cerebral hemispheres, particularly at the base of the telencephalon, and over the optic nerves, with non-specific binding over the eye (Fig. 5c). Light-microscope localization of specific $2-\left[{ }^{125}\right]$ ] iodomelatonin binding at day 48 gestation occurred over the mucosa and the muscular stroma of the gastrointestinal tract, and was limited to the epithelium of the trachea and bronchi in the respiratory system (Fig. 6).

Characterization of $2-\left[{ }^{125} \mathrm{I}\right]$ iodomelatonin binding sites in red deer fetuses revealed specific binding was time-dependent and saturable (Fig. 7a, b). Iodomelatonin, melatonin and 5-HT were found to compete with $2-\left[{ }^{125} \mathrm{I}\right]$ iodomelatonin binding with a similar order of potency to that found in other tissues (Fig. $7 \mathrm{c}$ ). Incubation of sections with $2-\left[{ }^{125}\right.$ I]iodomelatonin in the presence of $10^{-4}$ mol GTP $\gamma S \mathrm{I}^{-1}$ revealed a consistent inhibition of binding at all gestational ages and in all tissues measured (Fig. 7d).

\section{Discussion}

The present study demonstrates extensive localization of specific 2-[ ${ }^{125}$ I] iodomelatonin binding sites in the developing deer fetus, becoming apparent at around day 32 of gestation. Maternal melatonin crosses the placenta and signals gestational photoperiod to the fetus, which in red deer and sheep influences postnatal concentrations of plasma prolactin and the timing of puberty in the offspring (Helliwell et al., 1992; Adam et al., 1992, 1994). In adult and fetal sheep, hypothalamicpituitary disconnection studies have demonstrated that the pituitary is the mediator of the influence of melatonin on seasonal changes in plasma prolactin concentration (Lincoln and Clarke, 1994; Houghton et al., 1995). Melatonin receptors, in the present study, were clearly distinguished over the pars tuberalis and pars distalis of the pituitary of fetal red deer from day 48 of gestation onwards and almost certainly represent the site of action of melatonin on neonatal prolactin concentrations.

The presence of G-protein coupled melatonin receptors in numerous somatic tissues throughout development in deer fetuses is indicative of a further role for melatonin in growth and development in this species. Whether melatonin is derived from the dam or is acting as a paracrine agent in these tissues 
(a)

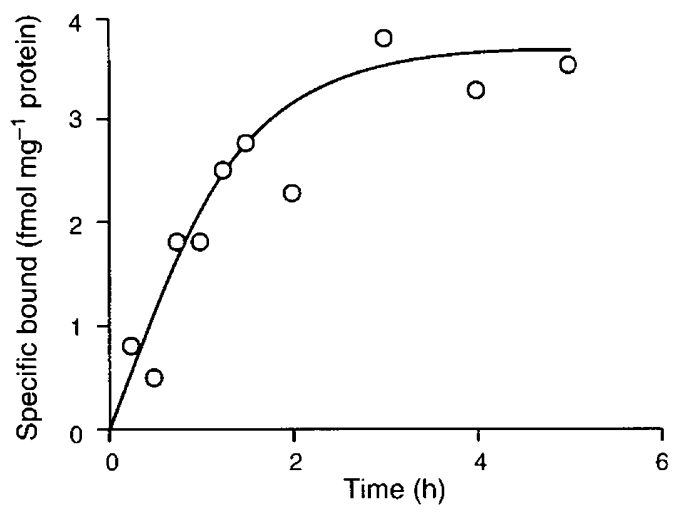

(c)

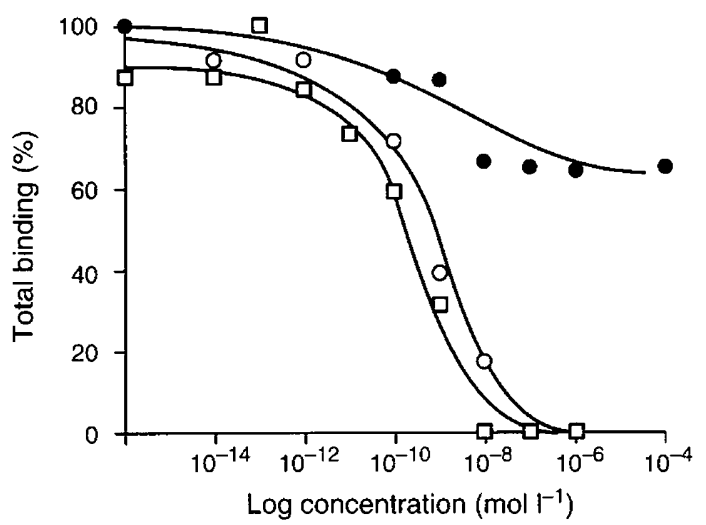

(b)

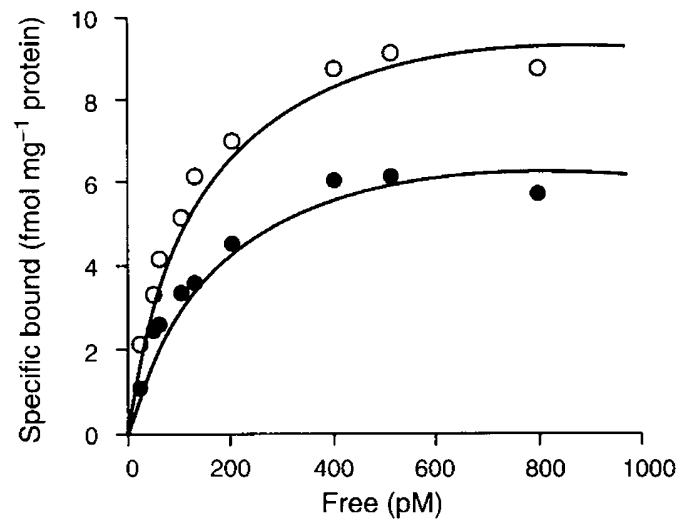

Fig. 7. (a) Time course of specific $2-\left[{ }^{125} \mathrm{I}\right]$ iodomelatonin binding to the fetal deer lung generated from quantitative in vitro autoradiography of sections from fetuses at day 37 and at day 50. (b) Typical saturation isotherms of $2-\left[{ }^{125}\right.$ I]iodomelatonin binding to the fetal deer lung homogenates from a fetus at day 192 in the presence $(\mathbf{O})$ or absence (O) of GTP $\gamma$ S. Values are derived from the mean of three separate experiments. $K_{d}=108 \pm 12.72 \mathrm{pmol}^{-1}$ and $B_{\max }=10.36 \pm 0.79 \mathrm{fmol} \mathrm{mg}^{-1}$ protein in the absence of GTP $\gamma \mathrm{S}$, and $K_{d}=118.66 \pm 31.70 \mathrm{pmol}^{-1}$ and $\mathrm{B}_{\max }=6.2 \pm 0.23 \mathrm{fmol} \mathrm{mg}^{-1}$ protein in the presence of GTP $\gamma \mathrm{S}$. (c) Competition curves generated from quantitative in vitro autoradiography of sections from a day 50 fetal deer lung. Total $2-\left[{ }^{125}[]\right.$ iodomelatonin binding in the presence of increasing concentrations of iodomelatonin (IMEL; $\square$ ) $\left(10^{-14}-10^{-6} \mathrm{~mol} \mathrm{l}^{-1}\right)$, melatonin (MEL; $\left.O\right)\left(10^{-14}-10^{-6} \mathrm{~mol}\right.$ $\left.\mathrm{I}^{-1}\right)$, and 5-HT $\left(10^{-11}-10^{-3} \mathrm{moll}^{-1}\right) . \mathrm{IC}_{50}$ values were IMEL $=2.9 \times 10^{-10} \mathrm{~mol} \mathrm{l}^{-1}, \mathrm{MEL}=4.9 \times 10^{-9} \mathrm{~mol}^{-1}$. (d) Histogram showing the specific $2-\left[{ }^{125}\right.$ I]jodomelatonin binding in different tissues of a fetus at day 52 in the absence ( $\square$ ) and presence ( $\boldsymbol{\square}$ ) of $10^{-4} \mathrm{~mol} \mathrm{GTP \gamma S} \mathrm{l}^{-1}$ generated by quantitative autoradiography in vitro.

remains to be investigated. A possible paracrine role for melatonin in gastrointestinal tract and cochlear innervation of deer fetuses is indicated by the reported synthesis of melatonin in the gut (Huether, 1993) and its presence in the cochlea of the ear in other species (Biesalski et al., 1988).

The presence of melatonin receptors in the fetal respiratory tract has been reported in sheep (Helliwell and Williams, 1992). In deer, specific 2-[ $\left.\left.{ }^{125}\right]\right]$ iodomelatonin binding occurred over the entire respiratory epithelium during early gestation supporting a putative role for melatonin in the development of the respiratory system. High concentrations of melatonin receptors also occurred over the brainstem and the optic nerves of fetal deer, whereas in the brainstem of adult deer $2-\left[{ }^{125}\right.$ l]iodomelatonin binding was restricted to the spinal tract of the trigeminal nerve (Williams et al., 1996). The role of melatonin receptors in these regions in fetal animals is unknown.
In conclusion, the localization of melatonin receptors over a number of central and somatic tissues in deer fetuses during early development confirms and extends the concept that melatonin plays a role not only in the transfer of photoperiodic information from the mother to the fetus but may also play a role in the growth and development of some fetal tissues and organs. Further research is required to ascertain the nature of this latter role.

The authors would like to thank $R$. Duthie for expert assistance with graphics. This work was funded by the Scottish Office Agriculture, Environment and Fisheries Department.

\section{References}

Adam CL, McDonald I, Moir CE and Pennie K (1988) Foetal development in red deer (Cervus elaphus) Animal Production 46 131-138 
Adam CL, Kyle CE and Young P (1992) Influence of prenatal photoperiod on postnatal prolactin secretion in red deer (Cervus elaphus) Journal of Reproduction and Fertility 95 959-964

Adam CL, Kyle CE and Young P (1994) Influence of prenatal photoperiod on timing of puberty in male red deer (Cervus elaphus) Journal of Reproduction and Ferilitity $100607-611$

Arey LB (1974) Developmental Anatomy WB Saunders Company, Philadelphia

Biesalski HK, Welker HA, Thalmann R and Vollrath L (1988) Melatonin and other serotonin derivatives in the guinea pig membranous cochlea Neuroscience Letters 91 41-46

Carlson LL, Weaver DR and Reppert SM (1991) Melatonin receptors and signal transduction during development in Siberian hamsters (Phodopus sungorus) Brain Research 568 345-349

Helliwell RJA and Williams LM (1992) Melatonin binding sites in the ovine brain and pituitary: characterization during the oestrus cycle Journal of Neuroendocrinology 4 287-294

Helliwell RJA and Williams LM (1994) The development of melatonin binding sites in the ovine fetus Journal of Endocrinology 142 475-484

Helliwell RJA, Wallace JM, Aitken RP and Robinson JJ (1992) Prenatal photoperiod times the onset of puberty in ewe lambs Journal of Reproduction and Fertility Abstract Series 10 Abstract 71

Horton TH (1984) Growth and reproductive development of male Microtus montanus is affected by prenatal photoperiod Biology of Reproduction 31 499-504

Horton TH (1985) Cross-fostering of voles demonstrates in utero effect of photoperiod Biology of Reproduction 33 934-939

Houghton DC, Young IR and McMillen IC (1995) Response of prolactin to different photoperiods after surgical disconnection of the hypothalamus and pituitary in sheep fetuses Journal of Reproduction and Fertility 104 199-206

Huether G (1993) The contribution of extrapineal sites of melatonin synthesis to circulating melatonin levels in higher vertebrates Experientia 49 665-670

Lee TM, Smale L, Zucker J and Dark J (1989) Influence of daylength experienced by dams on postnatal development of young meadow voles (Microtus pennsylvanius) Journal of Reproduction and Fertility $81337-342$

Lincoln GA and Clarke If (1994) Photoperiodically-induced cycles in the secretion of prolactin in hypothalamo-pituitary disconnected rams. Evidence for the translation of the melatonin signal in the pituitary gland Journal of Neuroendocrinology 6 251-260
Morgan PJ, Williams LM, Davidson G, Lawson W and Howell E (1989) Melatonin receptors on ovine pars tuberalis: characterization and autoradiographical localization Journal of Neuroendocrinology 1 1-4

Nazarali AJ, Gutkind IS and Saavedra JM (1990) Calibration of [ $\left.{ }^{125} \mathrm{I}\right]$ polymer standards with [ $\left.{ }^{125} \mathrm{I}\right]$ brain paste standards for use in quantitative receptor autoradiography Journal of Neuroscience Methods 30 247-253

Paxinos G, Ashwell KWS and Tork I (1994) Atlas of the Developing Rat Nervous System Academic Press, London

Rivkees SA and Reppert SM (1991) Appearance of melatonin receptors during embryonic life in Siberian hamsters (Phodopus sungorous) Brain Research 568 345-349

Stetson MH, Elliot JA and Goldman BD (1986) Maternal transfer of photoperiodic information influences the photoperiodic response of pubertal Djungarian hamsters (Phodopus sungorus) Biology of Reproduction 34 664-669

Stetson MH, Ray SL, Creyaufmiller N and Horton TH (1989) Maternal transfer of photoperiodic information in Siberian hamsters II. The nature of the maternal signal, time of signal transfer and the effect of the maternal signal on peripubertal reproductive development in the absence of photoperiodic input Biology of Reproduction 40 485-465

Steven DH (1975) Comparative Placentation Academic Press, London

Weaver DR and Reppert SM (1986) Maternal melatonin communicates daylength to the foetus in Diungarian hamsters Endocrinology 119 28612863

Weaver DR, Keohan GT and Reppert SM (1987) Definition of a prenatal sensitive period for maternal-foetal communication of daylength American Journal of Physiology 253 E701-E704

Weaver DR, Namboodiri MAA and Reppert SM (1988) lodinated melatonin mimics melatonin action and reveals discrete binding sites in fetal brain FEBS Letters 228 105-109

Williams LM, Martinoli MG, Titchener LT and Pelletier G (1991) The ontogeny of central melatonin binding sites in the rat Endocrinology 128 2083-2090

Williams LM, Hannah LT, Kyle CE and Adam CL (1996) Central melatonin receptors in red deer (Cervus elaphus) General and Comparative Endocrinology $1041-6$

Zemdegs JZ, McMillen JC, Walker DW, Thorburn DG and Nowak R (1988) Diurnal rhythms in plasma melatonin concentrations in the foetal sheep and pregnant ewe during late gestation Endocrinology 123 284-289 